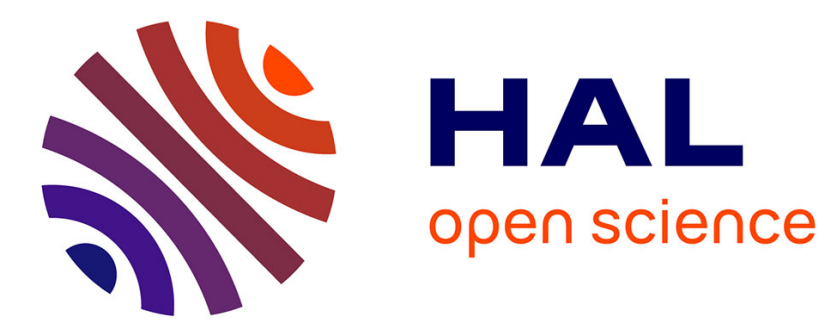

\title{
Detailed analysis of III-V/epi-SiGe tandem solar cell performance including light trapping schemes
}

R. Lachaume, M. Foldyna, G. Hamon, J. Decobert, R. Cariou, P. Roca I

Cabarrocas, J. Alvarez, J.P. Kleider

\section{- To cite this version:}

R. Lachaume, M. Foldyna, G. Hamon, J. Decobert, R. Cariou, et al.. Detailed analysis of III-V/epiSiGe tandem solar cell performance including light trapping schemes. Solar Energy Materials and Solar Cells, 2016, 166, pp.276-285. 10.1016/j.solmat.2016.11.023 . hal-01416344

\author{
HAL Id: hal-01416344 \\ https://hal.science/hal-01416344
}

Submitted on 20 Mar 2020

HAL is a multi-disciplinary open access archive for the deposit and dissemination of scientific research documents, whether they are published or not. The documents may come from teaching and research institutions in France or abroad, or from public or private research centers.
L'archive ouverte pluridisciplinaire HAL, est destinée au dépôt et à la diffusion de documents scientifiques de niveau recherche, publiés ou non, émanant des établissements d'enseignement et de recherche français ou étrangers, des laboratoires publics ou privés. 


\title{
Detailed analysis of III-V/epi-SiGe tandem solar cell performance including light trapping schemes
}

\author{
R. Lachaume ${ }^{\mathrm{a}, *}$, M. Foldyna ${ }^{\mathrm{b}}$, G. Hamon ${ }^{\mathrm{b}, \mathrm{c}}$, J. Decobert ${ }^{\mathrm{d}}$, R. Cariou ${ }^{\mathrm{b}, \mathrm{d}}$, P. Roca i Cabarrocas ${ }^{\mathrm{b}}$, \\ J. Alvarez ${ }^{\mathrm{a}}$, J.P. Kleider ${ }^{\mathrm{a}}$ \\ a GeePs, CNRS UMR 8507; CentraleSupélec, Univ Paris-Sud, Sorbonne Universités-UPMC Univ Paris 06, 11 rue Joliot-Curie, Plateau de Moulon, F-91192 \\ Gif-sur-Yvette Cedex, France \\ b LPICM-CNRS, Ecole Polytechnique, Université Paris-Saclay, 91128 Palaiseau, France \\ c TOTAL New Energies, 24 cours Michelet, 92069 Paris La Défense Cedex, France \\ d III-V Lab, 1 av. Augustin Fresnel, 91767 Palaiseau, France
}

\section{A R T I C L E I N F O}

\section{Keywords:}

Tandem solar cells

III-V on silicon

Epitaxial silicon germanium

Opto-electrical modeling

Light trapping

TCAD

RCWA

\begin{abstract}
A B S T R A C T
Recent developments have unlocked the main issues arising from the combination of III-V and silicon and have opened a new way to fabricate tandem solar cells. In this study we provide a detailed analysis of III-V/epi-SiGe tandem devices performance using opto-electrical models and parameters acquired from previous experimental realizations of single junction devices. At first, we present the validation of our top and bottom cells models by comparison with previously published solar cells. The analysis of the current matching and the impact of the Al content in AlGaAs absorber on the open circuit voltage is performed on a very wide range of thickness and $\mathrm{Al}$ content. The optimal configurations for tandems with thin film absorbers are found with an empirical expression. This expression relates the required bottom absorber thickness to the Al content for current matching in a flat tandem device. Low-temperature epitaxial SiGe growth on III-V materials is an inverted growth technique, meaning that the last material grown is the $\mathrm{Si}(\mathrm{Ge})$ bottom cell. We can thus easily texture the back of the bottom cell for higher photon absorption. The proposed nanostructurization of the back reflector shows that, to reach the same efficiency, only half of the thickness is required if a $2 \mathrm{D}$ grating is combined with a silver reflector. The detailed influence of the bulk and interface electrical quality in the epi-SiGe bottom cell is also assessed. Finally, the prediction of the tandem device performance according to different realistic scenarios is presented.
\end{abstract}

\section{Introduction}

The growing interest in new concepts of III-V/Si tandem solar cells arises from the need to reduce the cost of high efficiency III-V based multijunctions by using low cost substrates such as silicon [1-12]. Because it is a challenge to grow III-V materials directly onto Si wafers due to thermal expansion, lattice mismatch and polarity issues, other ways of combining III-V compounds and $\mathrm{Si}$ have been developed. Among them is the inverse metamorphic concept recently proposed by Cariou et al. $[3,13,14]$. In the latter approach, the Si bottom cell is deposited by low temperature $\left(<200{ }^{\circ} \mathrm{C}\right)$ Plasma Enhanced Chemical Vapor Deposition (PECVD) directly on the III-V top-cell, preventing the degradation of the electrical properties of the underlying III-V layers grown by Metal Organic Chemical Vapor Deposition (MOCVD) (see Fig. 1). Though the possibility to obtain a high crystalline quality for the epitaxial silicon (epi-Si) or silicon-germanium alloys (epi-SiGe) has already been demonstrated by the same authors, precise evaluations of both the electrical properties of the epi-Si absorber and the overall performance of such a tandem cell are mandatory. In this work we propose an in-depth electrical and optical analysis of the potential of this concept in terms of efficiency by means of simulations calibrated thanks to experimental electrical characterization data.

In a preliminary study [15], we have presented the simulation of an $\mathrm{Al}_{\mathrm{x}} \mathrm{Ga}_{1-\mathrm{x}} \mathrm{As} / \mathrm{epi}$-Si tandem cell considering neither defective layers nor light trapping schemes at the bottom. These previous simulations were aimed at investigating the impact of using a thin epitaxial bottom absorber instead of a thick Si wafer like in the other III-V/Si tandem cells. Notably, because the short circuit current $\left(J_{\mathrm{sc}}\right)$ of each sub-cell must be matched in such a 2-terminal integration design, we have shown that the composition $x$ and the thickness of the $\mathrm{Al}_{\mathrm{x}} \mathrm{Ga}_{1-\mathrm{x}} \mathrm{As}$ top cell should be adjusted to compensate the low absorption of the bottom cell. In other words, the optimum top cell band gap is different from the

\footnotetext{
* Corresponding author.

E-mail address: raphael.lachaume@geeps.centralesupelec.fr (R. Lachaume).
} 


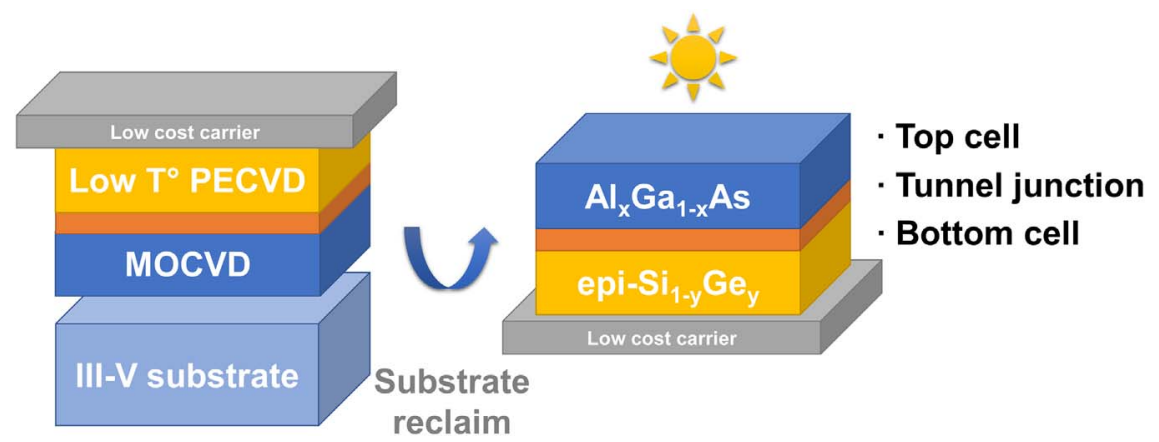

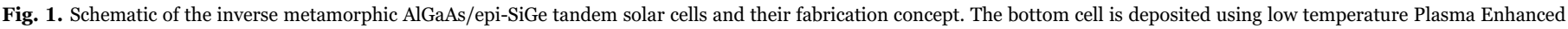

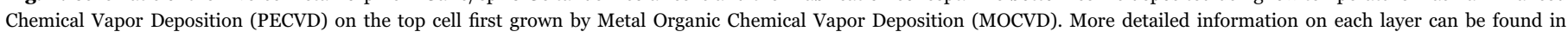
Table 1.

values generally calculated for fully absorbing $\mathrm{Si}$ based tandem cells and depends on the attainable epi-Si absorber thickness.

Furthermore, we have shown that efficiencies over 33\% could be achieved by replacing the epi-Si absorber with epi-SiGe, for which the absorption coefficient is considerably higher. However, a thickness of $20 \mu \mathrm{m}$ was still necessary, which increases the cost of epitaxial films. Therefore, in this work we have optimized the AlGaAs/epiSiGeAlGaAs/epi-SiGe tandem cell structure and investigated the benefits of including light-trapping schemes in order to determine how far we can relax this thickness constraint.

In parallel, the critical aspect of the presence of defects in the epiSiGe has to be carefully taken into account to design optimal fabrication strategies for this novel concept suitable for making highly efficient tandem cells. Hence, along with the construction of our tandem cell model, we have experimentally quantified the epi-SiGe electrical quality by retrieving the interface and bulk defects densities and the resulting effective diffusion length $\left(L_{d}\right)$ in the epitaxial layer. This has been done by comparing simulations with current-voltage characterization obtained on single epi-Si(Ge) solar cells. This allows us to calculate and discuss the predicted performance of AlGaAs/epi-SiGe tandem cells according to several scenarios.

\section{Modeling and experimental inputs}

\subsection{Modeling strategy}

The simulated AlGaAs/epi-SiGe tandem structure, which has been optimized with respect to our previous studies [15], is described in Table 1. The principal modifications, from top to bottom, are as follows. The Anti-reflective Coating (ARC) thickness has been adjusted to minimize the cell reflectivity. The top cell absorber is $\mathrm{Al}_{\mathrm{x}} \mathrm{Ga}_{1-\mathrm{x}} \mathrm{As}$, which composition $x$ can be tuned to adjust its band gap and thus match the top and bottom cells $\mathrm{J}_{\mathrm{sc}}$. Its emitter thickness has been reduced to $100 \mathrm{~nm}$ to slightly improve the $V_{\text {oc }}$, while the base thickness is fixed to $1 \mu \mathrm{m}$, assuring a sufficient light absorption in this layer [15]. The thickness of the tunnel junction, which is modeled as an excellent electrical contact, has also been reduced to decrease its parasitic light absorption. The bottom absorber is fixed to epi-Si $\mathrm{Si}_{0.73} \mathrm{Ge}_{0.27}$, which thickness is variable. Finally, to enhance the light path inside the bottom absorber, we studied different back metallization schemes on the amorphous silicon layer (a-Si:H): a simple aluminum layer, a bilayer of $\mathrm{ZnO}(25 \mathrm{~nm})$ on silver and a $2 \mathrm{D}$ grid composed of the line grating with pitch of $750 \mathrm{~nm}$ on $\mathrm{ZnO}$ and $\mathrm{Ag}$ substrate.

We have modeled the tandem solar cell using TCAD numerical simulation tools [16], which solve the Poisson, electroneutrality and transport equations (Drift Diffusion) self-consistently on a 2D mesh. Band structure, electrical transport and recombination parameters for III-V materials and amorphous and crystalline silicon were chosen in agreement with literature values [17-22] and are composition and doping dependent. To simulate the current density versus voltage
Table 1

Simulated AlGaAs/epi-SiGe tandem cell structure based on previous developments [15]. $\mathrm{E}_{\mathrm{C}}-\mathrm{E}_{\mathrm{F}}$ is the hydrogenated amorphous silicon (a-Si:H) activation energy i.e. the energy difference between the Fermi level $\left(\mathrm{E}_{\mathrm{F}}\right)$ and the bottom of the conduction band $\left(\mathrm{E}_{\mathrm{C}}\right)$ in the a-Si:H layer.

\begin{tabular}{|c|c|c|c|c|}
\hline & Material & Role & $\begin{array}{l}\text { Thickness } t \\
(\mu \mathrm{m})\end{array}$ & $\begin{array}{l}\text { Net doping } \\
\mathrm{N}_{\mathrm{A}} / \mathrm{N}_{\mathrm{D}} \\
\left(\mathrm{cm}^{-3}\right)\end{array}$ \\
\hline \multirow[t]{5}{*}{ Top cell } & $\mathrm{SiO}_{2} / \mathrm{TiO}_{2}$ & $\begin{array}{l}\text { Anti-Reflective } \\
\text { Coating (ARC) }\end{array}$ & $0.085 / 0.05$ & - \\
\hline & $\mathrm{Al}_{0.85} \mathrm{Ga}_{0.15} \mathrm{As}(\mathrm{p})$ & Window & 0.035 & $2 \times 10^{18}$ \\
\hline & $\mathrm{Al}_{\mathrm{x}} \mathrm{Ga}_{1-\mathrm{x}} \mathrm{As}(\mathrm{p})$ & Emitter & 0.1 & $2 \times 10^{18}$ \\
\hline & $\mathrm{Al}_{\mathrm{x}} \mathrm{Ga}_{1-\mathrm{x}} \mathrm{As}(\mathrm{n})$ & Base & 1 & $3 \times 10^{17}$ \\
\hline & $\mathrm{Al}_{0.6} \mathrm{Ga}_{0.4} \mathrm{As}(\mathrm{n})$ & $\begin{array}{l}\text { Back Surface } \\
\text { Field (BSF) }\end{array}$ & 0.1 & $2 \times 10^{18}$ \\
\hline \multirow{2}{*}{$\begin{array}{c}\text { Tunnel } \\
\text { junc- } \\
\text { tion }\end{array}$} & GaAs $(\mathrm{n}++)$ & $\mathrm{n}++$ layer & 0.01 & $1 \times 10^{19}$ \\
\hline & GaAs $(\mathrm{p}++)$ & $\begin{array}{l}\mathrm{p}++ \text { layer and } \\
\text { emitter of the } \\
\text { bottom cell }\end{array}$ & 0.01 & $1 \times 10^{19}$ \\
\hline \multirow[t]{3}{*}{$\begin{array}{l}\text { Bottom } \\
\text { cell }\end{array}$} & epi-Si ${ }_{0.73} \mathrm{Ge}_{0.27}(\mathrm{n})$ & Base & $\begin{array}{l}\text { Variable (5- } \\
41)\end{array}$ & $1 \times 10^{14}$ \\
\hline & a-Si:H (i / n) & $\mathrm{BSF}$ & 0.012 & $\begin{array}{l}\mathrm{E}_{\mathrm{C}}-\mathrm{E}_{\mathrm{F}} \sim \\
0.2 \mathrm{eV}\end{array}$ \\
\hline & $\mathrm{Al}$ or $\mathrm{ZnO} / \mathrm{Ag}$ & $\begin{array}{l}\text { Flat metal } \\
\text { contact }\end{array}$ & $\begin{array}{l}0.4 \text { or } 0.025 \\
/ 0.4\end{array}$ & - \\
\hline
\end{tabular}

characteristics, J(V), under AM1.5 g spectrum, realistic photogeneration profiles have been calculated through the entire structure, neglecting optical shading due to metal contacts and using the optical indexes of the various layers as inputs. The latter are composition dependent and are obtained by interpolation of experimental data found in literature, mainly coming from ellipsometry measurements $[16,17]$. Transfert Matrix Method (TMM) is used to take multireflections and interferences into account for $\mathrm{Al}$ and $\mathrm{ZnO} / \mathrm{Ag}$ back reflector cases, assuming perfectly flat interfaces (no surface texturation).

However, to simulate the advanced light trapping scheme, the rigorous coupled wave analysis (RCWA) has been used [23]. The method is based on the solution of Maxwell equations by expanding the periodic electromagnetic field inside the structure into Fourier series and converting the problem mathematically to an eigenvalue problem. The boundary conditions at interfaces are solved using the scattering matrix approach [24] while the convergence of the method is improved by applying inverse rules [25]. The analysis of the absorptance in each material layer has been done by differentiating normal components of Poynting vector at material boundaries. Spectral dependence of the absorptance in each layer is integrated using the AM $1.5 \mathrm{~g}$ solar spectrum to calculate photogeneration current as well as impact of the parasitic losses on the device performance. The thickness of the SiGe absorber layer as well as the geometry of the grating has been adjusted to match the current of the front junction and thus 
maximize the device performance while reducing amount of required material.

This physics-based modeling has the advantage to provide more realistic performance predictions than conventional efficiency calculations based on simplified assumptions, but model parameters must be carefully set and adjusted if necessary to reproduce experimental data. Consequently, to improve the accuracy of our results, we have calibrated our models to fit either in-house or literature experimental data. This is also a convenient way to extract scarcely accessible but useful parameters such as defect densities or effective diffusion lengths inside the devices. We explain this procedure in the following Sections 2.2 and 2.3 .

\subsection{Validation of our top cell model}

To validate the full set of parameters used to model the III-V materials in our tandem cell, we have simulated six different GaAs or AlGaAs solar cells for which the detailed architecture and electrical characterization data were provided in the literature [26,27]. These cells comprise an n-type cell and several p-type ones with different $\mathrm{Al}$ compositions. Note that the n-type cell comprises an ARC contrary to p-type cells, which induces a strong difference in $J_{\mathrm{sc}}$. As displayed in Fig. 2(a) and (b), we could successfully match the author's data such as AM1.5 g J(V) or quantum efficiency curves. To achieve this, we needed to adjust very few fitting parameters, testifying the suitability of our modeling. Results for $\mathrm{Al}_{\mathrm{x}} \mathrm{Ga}_{1-\mathrm{x}} \mathrm{As}$ cells with $x=0$ and 0.05 could be fitted by adjusting only the lumped series resistance value. This parameter takes into account the resistive losses that are due to lateral conduction and metallization which are not simulated in this study for the sake of simplification. For $x=0.2$ and 0.37 , the $\mathrm{Al}$ composition had to be slightly adjusted to fit the band gap edge visible in the IQE curves of Fig. 2(b). Finally, for the highest Al compositions $x=0.27$ and 0.37, the Shockley-Read-Hall (SRH) recombination lifetime in the AlGaAs absorber had to be reduced down to $0.3 \mathrm{~ns}$ (see Table 2) to take into account the reduced short wavelength response observed in the IQE. This layer quality reduction is fully consistent with an increased amount of doping related defects as explained in [27]. For the simulation of the tandem, we have kept the standard SRH lifetime values in the top cell model.

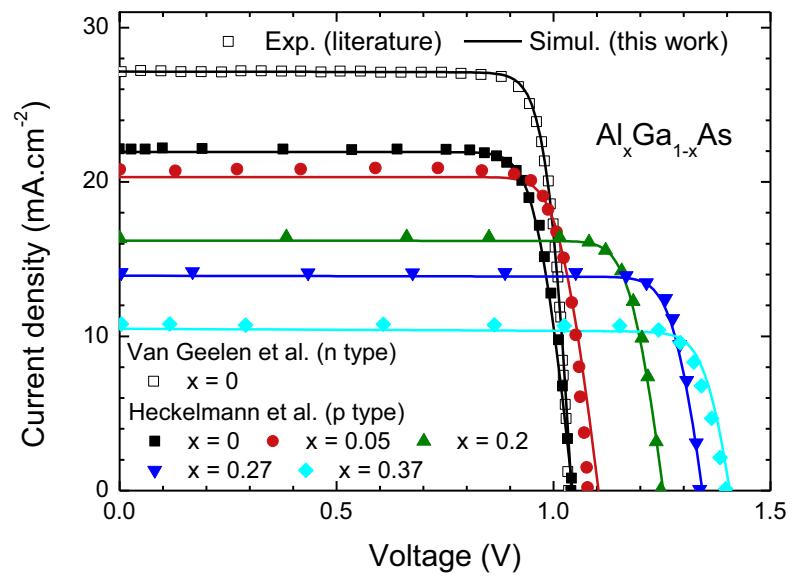

\subsection{Validation of our bottom cell model}

To validate our bottom cell model, we have simulated four epi$\mathrm{Si}(\mathrm{Ge})$ heterojunction solar cells that were formerly fabricated using low-temperature plasma enhanced chemical vapor deposition (PECVD) process to demonstrate the feasibility of using thin epitaxial layers as high quality absorbers $[4,14,20,22]$. As depicted in Fig. 3(a), in these single junction cells the epi-Si or epi-SiGe layers are grown on a heavily doped (p++) Si substrate and are from $1.9 \mu \mathrm{m}$ to $4.2 \mu \mathrm{m}$ thick. An (i/ n) hydrogenated amorphous silicon bilayer and an ITO layer are deposited on top to serve as surface passivation, emitter and antireflective coating, respectively. The experimental AM1.5 g J(V) curves corresponding to these four solar cells have been reported in Fig. 3(b), in which we also show our fitting simulation results.

To achieve this fit we have constructed an epi-Si model based upon [22], which was adapted to absorber thicknesses $\left(t_{\text {epi }}\right)$ below $2.4 \mu \mathrm{m}$, and we have extended it for thicknesses of $3.2 \mu \mathrm{m}$ and $4.2 \mu \mathrm{m}$ and for epi-SiGe. Most important material parameters are given in Table 3.

Our fitting procedure can be simplified as follows. We first have matched the EQE (not shown here) and $J_{\mathrm{sc}}$ by adjusting the optical shading $(8 \pm 1.5 \%)$, the thickness of the a-Si:H layer $(12 \pm 2 \mathrm{~nm})$ and the $(\mathrm{p}++) \mathrm{Si}$ substrate lifetime $\left(1-6 \times 10^{-8} \mathrm{~s}\right)$ for each cell. Then we have varied the epi-Si(Ge) bulk defects density to approach the Fill Factor (FF) value, and the epi-Si(Ge) $/(\mathrm{p}++)$ Si interface defects density to adjust the $\mathrm{V}_{\text {oc }}$ value. The fitting parameters are given in Table 4 . We have also calculated an effective diffusion length $L_{d}$ inside the epitaxial layer, which is a useful way of assessing the quality of the layer. This parameter integrates the effects of both interface and bulk defects for a given absorber thickness. We used Eq. (1) to calculate $L_{d}$, where $k_{B}$ is the Boltzmann constant, $T$ is the temperature fixed to $300 \mathrm{~K}, q$ is the elementary charge, $\mu_{p}$ is the minority carrier mobility in the epi-Si(Ge) layer and $\tau_{p}$ is the minority carrier lifetime calculated using Eq. (2). $\Delta p$ and $R$ are the excess minority carrier density and the total recombination rate, respectively, averaged in the epi-Si(Ge) layer of a solar cell at open-circuit voltage.

$L_{d}=\sqrt{\left(k_{B} T / q\right) \times \mu_{p} \tau_{p}}$

$\tau_{p}=\Delta p / R$

Looking at Table 4, we can clearly see that the bulk quality of the epi-Si material is improving with $t_{\text {epi }}$, as a result of an exponentially decreasing average bulk defects density $N_{b}$, also explaining the

b)

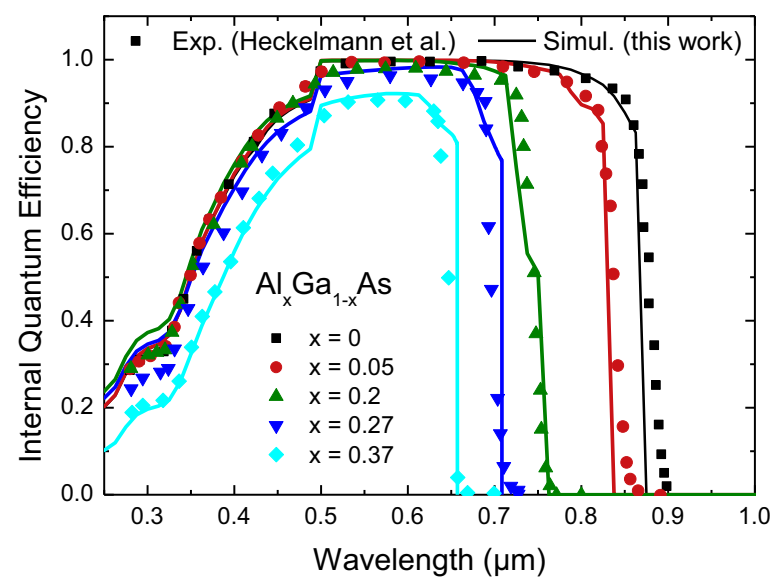

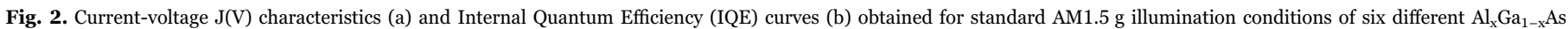

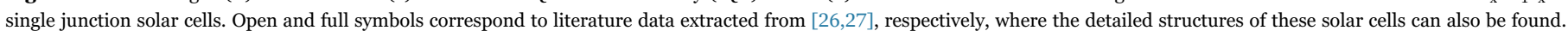

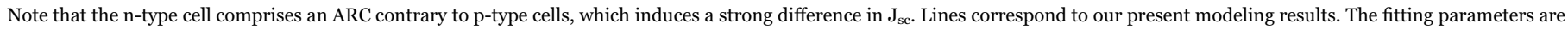
given in Table 2. 
Table 2

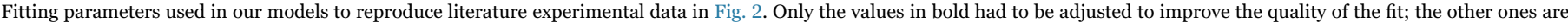
default values that we chose in our modeling in agreement with [17-19]. ' $a$ ' refer to the solar cell structure of [26] while 'b' refers to the solar cell structure of [27].

\begin{tabular}{|c|c|c|c|c|c|c|c|c|}
\hline & \multicolumn{2}{|c|}{ Al comp. $(x)$} & \multirow{2}{*}{$\begin{array}{l}\text { Band gap Eg } \\
(\mathrm{eV})\end{array}$} & \multirow{2}{*}{$\begin{array}{l}\text { SRH lifetime in emitter } \\
\tau_{\mathrm{SRH}} \text {, emitter }(\mathrm{s})\end{array}$} & \multirow{2}{*}{$\begin{array}{l}\text { SRH lifetime in base } \\
\tau_{\mathrm{SRH}} \text {, base }(\mathrm{s})\end{array}$} & \multirow{2}{*}{$\begin{array}{l}\text { Radiative recombination coefficient B } \\
\left(\mathrm{cm}^{-3} \mathrm{~s}^{-1}\right)\end{array}$} & \multirow[t]{2}{*}{ Shading (\%) } & \multirow{2}{*}{$\begin{array}{l}\text { Series resistance } R_{S} \\
\left(\Omega \mathrm{cm}^{2}\right)\end{array}$} \\
\hline & Exp. & Fit & & & & & & \\
\hline \multirow[t]{3}{*}{$\mathrm{a}$} & 0 & 0 & 1.42 & $3 \times 10^{-6}$ & $3 \times 10^{-6}$ & $2 \times 10^{-10}$ & 6.5 & 1.5 \\
\hline & 0 & 0 & 1.42 & $3 \times 10^{-6}$ & $3 \times 10^{-6}$ & $2 \times 10^{-10}$ & 0 & 2.5 \\
\hline & 0.05 & 0.05 & 1.48 & $3 \times 10^{-6}$ & $3 \times 10^{-6}$ & $1.8 \times 10^{-10}$ & 0 & 3 \\
\hline \multirow[t]{3}{*}{$\mathrm{b}$} & 0.2 & 0.18 & 1.64 & $3 \times 10^{-6}$ & $3 \times 10^{-6}$ & $1.8 \times 10^{-10}$ & 0 & 3 \\
\hline & 0.27 & 0.27 & 1.75 & $5 \times 10^{-10}$ & $3 \times 10^{-6}$ & $1.8 \times 10^{-10}$ & 0 & 3 \\
\hline & 0.37 & 0.38 & 1.89 & $3 \times 10^{-10}$ & $4 \times 10^{-9}$ & $1.8 \times 10^{-10}$ & 0 & 3 \\
\hline
\end{tabular}

a)

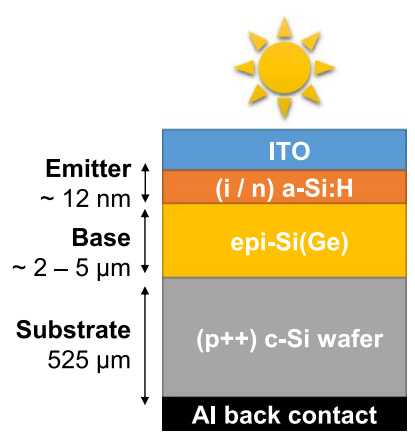

b)

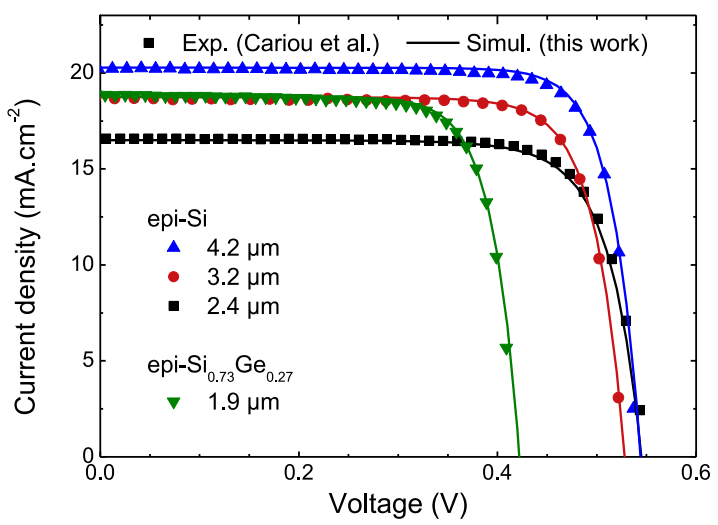

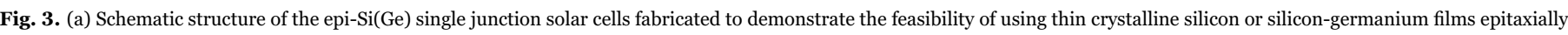

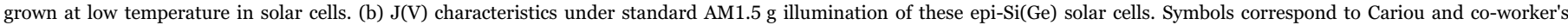

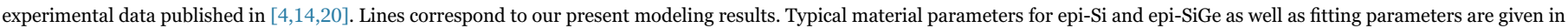
Table 3 and Table 4, respectively.

Table 3

Compilation of typical material parameters for epi-Si and epi-SiGe from $\mathrm{Si}$ and $\mathrm{SiGe}$ databases [17] for common parameters and from [21] for epi-Si electron and hole mobility (also used in [22]). The unknown mobility values in epi-SiGe are fixed to intermediate values between known ones for epi-Si and for SiGe [17].

\begin{tabular}{llllll}
\hline Material & $\begin{array}{l}\text { Relative } \\
\text { permittivity } \\
\varepsilon / \varepsilon_{O}\end{array}$ & $\begin{array}{l}\text { Electron } \\
\text { affinity } \chi \\
(\mathrm{eV})\end{array}$ & $\begin{array}{l}\text { Band } \\
\text { gap } \\
E g \\
(\mathrm{eV})\end{array}$ & $\begin{array}{l}\text { Electron } \\
\text { mobility } \\
\mu_{n}\left(\mathrm{~cm}^{2} \mathrm{~V}^{-}\right.\end{array}$ & $\begin{array}{l}\text { Hole } \\
\left.\mathrm{s}^{-1}\right)\end{array}$ \\
\hline $\begin{array}{c}\left.\mathrm{cm}^{2} \mathrm{~V}^{-1} \mathrm{~s}^{-1}\right) \\
\text { epi-Si }\end{array}$ & 11.9 & 4.05 & 1.12 & 400 & 125 \\
epi-Si ${ }_{0.73} \mathrm{Ge}_{0.27}$ & 12.9 & 4.04 & 1.01 & 247 & 125 \\
\hline
\end{tabular}

\section{Table 4}

Fitting parameters used in our models to reproduce experimental data in Fig. 3(b). The effective diffusion length is calculated using Eq. (1) and results from the incorporation of both interface and bulk defects. The interface defects reported here are located at the epi$\mathrm{Si}(\mathrm{Ge}) /(\mathrm{p}++) \mathrm{Si}$ interface. At the (i/ n) a-Si:H / epi-Si(Ge) interface, a fixed defects density of $6 \times 10^{11} \mathrm{~cm}^{-2}$ is considered. The capture cross sections are fixed to $10^{-16} \mathrm{~cm}^{2}$ and $10^{-17} \mathrm{~cm}^{2}$ for charged and neutral defects in the epi-SiGe bulk while they are fixed to $10^{-15} \mathrm{~cm}^{2}$ and $10^{-16} \mathrm{~cm}^{2}$ for charged and neutral defects at the interfaces as suggested in [22]. The value of the lumped series resistance is fixed to $0.1 \Omega \mathrm{cm}^{2}$ for the epi-Si cells and to $0.02 \Omega \mathrm{cm}^{2}$ for the epi-SiGe cell.

\begin{tabular}{lllll}
\hline Material & $\begin{array}{l}\text { Thickness } \\
t_{\text {epi }}(\mu \mathrm{m})\end{array}$ & $\begin{array}{l}\text { Bulk defects } \\
\text { density } N_{b} \\
\left(\times 10^{14} \mathrm{~cm}^{-3}\right)\end{array}$ & $\begin{array}{l}\text { Interface } \\
\text { defects density } \\
N_{i}\left(\times 10^{12} \mathrm{~cm}^{-2}\right)\end{array}$ & $\begin{array}{l}\text { Effective } \\
\text { diffusion } \\
\text { length } L_{d} \\
(\mu \mathrm{m})\end{array}$ \\
\hline epi-Si & 2.4 & 26 & 1.5 & $\sim 14$ \\
& 3.2 & 12 & 1.8 & $\sim 13$ \\
epi-Si & 4.2 & 1 & 1.7 & $\sim 16$ \\
& 1.9 & 1 & 2.9 & $\sim 9$ \\
\hline
\end{tabular}

improvement of FF of the cells (77\%, 79\% and $80.5 \%$ for the $2.4,3.2$ and $4.2 \mu \mathrm{m}$ cases, respectively, as detailed in [4]). The interface defects density $N_{i}$ is almost independent of the absorber thickness, further indicating that the defective region in the epitaxial layer $\left(N_{b}>\right.$ $10^{16} \mathrm{~cm}^{-3}$ ) should be constrained to the first hundreds of nanometers of deposited material (we have estimated this defective zone to $0.6 \mu \mathrm{m}$ using data in Table 4) and that the rest of the epitaxial layer should be of better quality $\left(N_{b}<10^{14} \mathrm{~cm}^{-3}\right)$. Looking now at the $L_{d}$ values, we notice a slight improvement of this parameter for $t_{\text {epi }}$ $=4.2 \mu \mathrm{m}$, correlated to the better bulk quality. Though, $L_{\boldsymbol{d}}$ seems to be mainly limited by interface defects. Concerning epi-Si ${ }_{0.73} \mathrm{Ge}_{0.27}$, we can observe that the electrical quality of this material is also good since $L_{d}$ $(\sim 9 \mu \mathrm{m})$ is $\sim 5$ times higher than the thickness of the absorber $(1.9 \mu \mathrm{m})$ like for epi-Si cases. Besides, $N_{b}$ is lower for epi-Si $\mathrm{Si}_{0.73} \mathrm{Ge}_{0.27}$ than for an equivalent value of epi-Si thickness.

In Section 3.1 concerning the tandem simulation, the defect densities are fixed to ideally low values to study the ideal case with high $L_{d}$. Then, in 3.2, the effect of $L_{d}$ on the tandem performance is investigated by varying interface and bulk defects independently. Finally, the fitted defects densities in Table 4 are used to constitute three different scenarios, which will be discussed in 3.3.

\section{Results and discussion}

\subsection{Optimization of the tandem performance}

\subsubsection{Opto-electrical model with TMM}

The objective of this section is to determine the influence of the light-trapping schemes placed at the back of the tandem solar cell structure described in Table 1. At this stage, we consider an ideal case, called scenario \#1 in the rest of the paper, where defects densities are 
a)

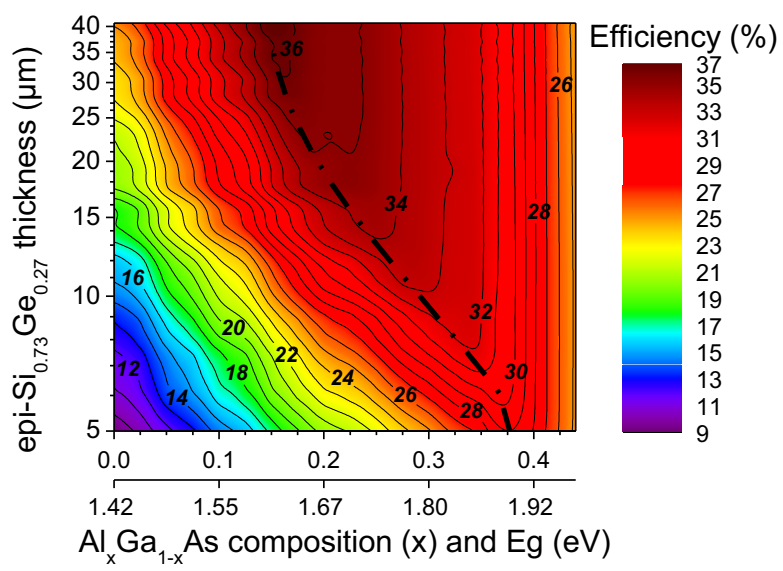

b)

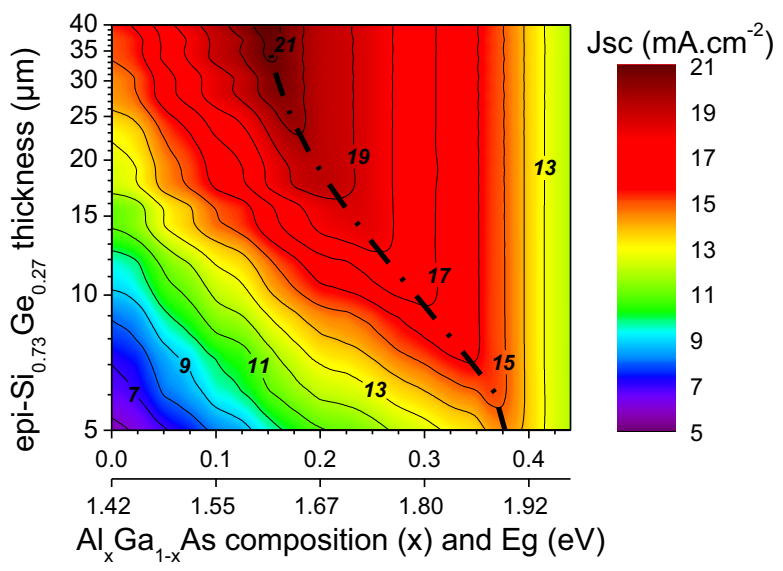

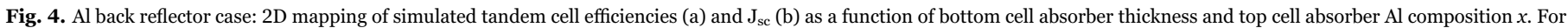

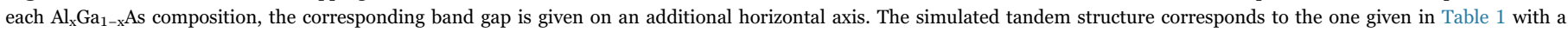
simple $\mathrm{Al}$ reflector.

set to very low values.

The Al back reflector case is considered first. We have calculated $\mathrm{Al}_{\mathrm{x}} \mathrm{Ga}_{1-\mathrm{x}} \mathrm{As} / \mathrm{epi}-\mathrm{Si}_{0.63} \mathrm{Ge}_{0.27}$ tandem efficiencies as a function of epiSiGe thickness and composition $x$. A contour map is obtained as shown in Fig. 4(a). An advantageous direct consequence of the optimization of the tandem structure (c.f. 2.1) is that $29 \%$ efficiency can be obtained for $t_{\text {epi }}=5 \mu \mathrm{m}$ while $\sim 9 \mu \mathrm{m}$ was required for the previously published structure [15] to exhibit the same efficiency. Also note that the maximum efficiency is now $35.8 \%$ instead of $33.9 \%$ in the given range $5 \mu \mathrm{m} \leq t_{\text {epi }} \leq 30 \mu \mathrm{m}$.

Fig. 4(b) represents the $J_{\text {sc }}$ map corresponding to the efficiency calculations of Fig. 4(a). A black dotted line is also reported, aimed at showing the best $\left(x, t_{\text {epi }}\right)$ pairs for which the top and bottom cells individual currents are matched. This line has been determined by fitting the $\mathrm{Al}$ compositions leading to the highest tandem $J_{\mathrm{sc}}$ for each epi-SiGe thickness. A fitting correlation coefficient above 0.99 has been obtained for $t_{\text {ep } i} \geq 6 \mu \mathrm{m}$, using the decaying exponential function of Eq. (3), combined with $x_{\boldsymbol{O}}, x_{\boldsymbol{1}}$ and $t_{\boldsymbol{O}}$ parameters given in the first row of Table 5. We also give an alternative to Eq. (3) with Eq. (4), to be able to retrieve the required value of $t_{\text {epi }}$ given a value of $x$, following a logarithmic dependence.

$x=x_{0}+x_{1} \times \exp \left(-\frac{t_{e p i}}{t_{0}}\right)$

$t_{e p i}=t_{0} \quad \times \ln \left[\frac{x_{1}}{\left(x-x_{0}\right)}\right]$

The same black dotted line is also reported in Fig. 4(a). As expected in current matching conditions, it matches the areas where the efficiency is maximum. Interestingly, we can also remark in the efficiency map that equivalent efficiency values can be obtained for slightly higher compositions $x$, i.e. for slightly current mismatched sub cells. This can be explained by the fact that when $x$ increases, so does

Table 5

Parameter values of Eq. (3) obtained by fitting the maximum $J_{\mathrm{sc}}$ areas of Fig. 4(b) for the case "Al reflector" and Fig. 5(b) for the case " $\mathrm{ZnO} / \mathrm{Ag}$ reflector", giving the current matching conditions.

\begin{tabular}{llll}
\hline Parameter & $x_{O}$ & $x_{1}$ & $t_{O}$ \\
\hline Al reflector $^{\mathrm{a}}$ & $0.140 \pm 0.001$ & $0.426 \pm 0.003$ & $9.63 \pm 0.10 \mu \mathrm{m}$ \\
$\mathrm{ZnO} / \mathrm{Ag}$ reflector & $0.140 \pm 0.001$ & $0.355 \pm 0.008$ & $7.21 \pm 0.16 \mu \mathrm{m}$ \\
\hline
\end{tabular}

a In the $\mathrm{Al}$ reflector case, the formula is valid only for $\mathrm{t}_{\mathrm{epi}} \geq 6 \mu \mathrm{m}$. Optimum $\mathrm{Al}$ composition for $t_{\text {epi }}=5 \mu \mathrm{m}$ is $x \sim 0.38$ as inferred from calculations of Fig. 4(b). the top cell band gap, implying the increase of open circuit voltage of the tandem. In fact, this higher $\mathrm{V}_{\mathrm{oc}}$ value can compensate to some extent the decrease of $J_{\mathrm{sc}}$ due to the current mismatch. Therefore, with this observation we highlight that having the sub cells currents matched is not necessarily a strict requirement to obtain the maximum efficiency of a given 2-terminal tandem architecture, contrary to the generally accepted view. For a given dependence of $\mathrm{V}_{\text {oc }}$ upon the band gap, the strictness of the current matching condition is linked to the carrier collection efficiency near band edge visible in an EQE curve: the higher the near band edge quantum efficiency, the stricter the current matching condition.

Given the strong correlation of the $\mathrm{J}_{\mathrm{sc}}$ and the efficiency contour maps seen in Fig. 4, it is mandatory to maximize the bottom cell generated current. This can be achieved by improving the internal reflectivity of the back contact metallization.

For this purpose we now propose to replace the $\mathrm{Al}$ back contact by a $\mathrm{ZnO}(25 \mathrm{~nm}) / \mathrm{Ag}$ bi-layer. The resulting efficiency and $\mathrm{J}_{\mathrm{sc}}$ calculations are given in Fig. 5. Due to a better optical coupling, an enhanced light absorption in the bottom cell occurs, leading to higher $J_{\mathrm{sc}}$ values for low epi-SiGe absorber thicknesses and resulting in improved tandem efficiencies. This modification also has a consequence on the current matching. The fit of the $\left(x, t_{\text {epi }}\right)$ pairs corresponding to the current matching conditions has been done again using Eq. (3) and is represented by another black dotted line on the 2D contour maps. We can see that this new line is translated to lower $x$ values compared to the one in Fig. 4. The new fitting coefficients are given in the second row of Table 5. The fitting correlation coefficient is now above 0.97 , a bit less that in the previous case. This difference can be due to significant oscillations present in the $\mathrm{J}_{\mathrm{sc}}$ contour map, which may come from the highly non-linear behavior of the absorptance of the epiSiGe layer due to optical interferences (see Fig. 7).

A physical meaning can be given to the coefficients in Table 5. The $x_{O}$ value is the same in both reflector cases, unsurprisingly. Indeed, $x_{O}$ is the limit of the $x\left(t_{\text {epi }}\right)$ function when $t_{\text {epi }}$ tends to infinite thickness and thus it is not supposed to depend on the back light trapping scheme. The corresponding AlGaAs band gap for $x_{O}=0.14$ is $\sim 1.6 \mathrm{eV}$, which is found to be consistent with [1]. $x_{O}+x_{1}$ is the value of the $x\left(t_{e p i}\right)$ function when $t_{\text {epi }}$ tends to $0 \mu \mathrm{m}$, i.e. when the absorption in the bottom cell tends to very low values. It thus gives an estimate of the highest $\mathrm{Al}$ composition that is required for matching the sub cells currents. $t_{O}$ is a characteristic thickness linked to the light trapping effectiveness in the bottom cell: the lower it is, the higher is the light absorption in epi-SiGe.

Additionally, combining fitting equations for $\mathrm{Al}$ and $\mathrm{ZnO} / \mathrm{Ag}$ back 
a)

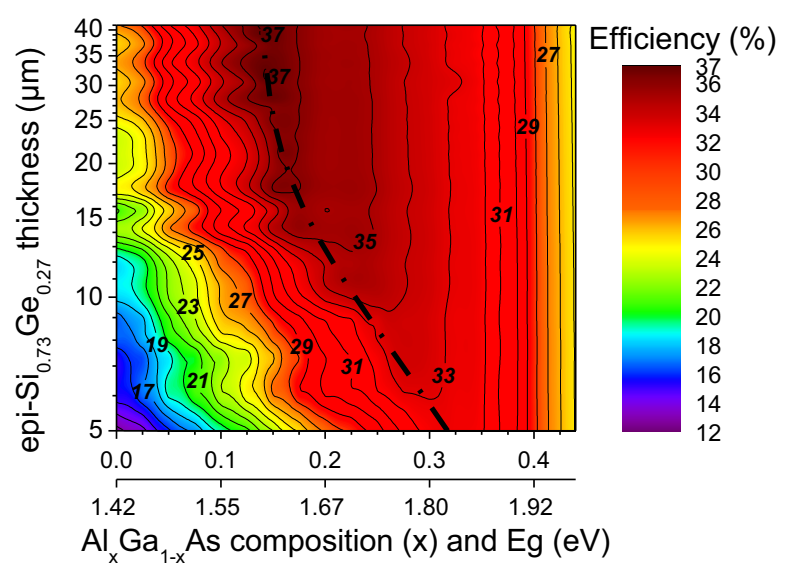

b)

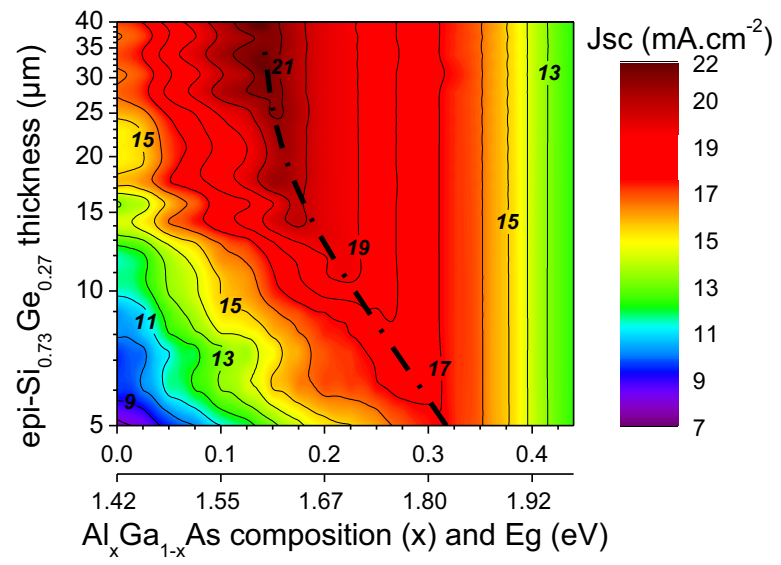

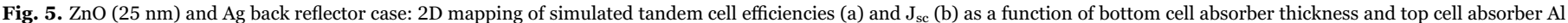
composition $x$. For each $\mathrm{Al}_{\mathrm{x}} \mathrm{Ga}_{1-\mathrm{x}} \mathrm{As}$ composition, the corresponding band gap is given on an additional horizontal axis.

reflectors allowed us to derive the estimated epi-SiGe thickness reduction factor $\mathrm{F}$ defined as the factor by which it is possible to divide the bottom epi-SiGe thickness if $\mathrm{ZnO} / \mathrm{Ag}$ is used at the back instead of $\mathrm{Al}$, while keeping the tandem $\mathrm{J}_{\text {sc }}$ constant. $\mathrm{F}$ can be calculated using Eq. (5), where parameters with subscript $\mathrm{Al}$ or $\mathrm{ZnO} / \mathrm{Ag}$ refer to the respective coefficients for $\mathrm{Al}$ and $\mathrm{ZnO} / \mathrm{Ag}$ back reflector cases in Table 5.

For thick epi-SiGe layers $t_{\text {epi, } A l}, F$ tends to a constant value $\sim 1.3$ while for $15 \mu \mathrm{m}, F \sim 1.5$. It is thus possible to achieve the same tandem $\mathrm{J}_{\mathrm{sc}}$ by reducing the epi-SiGe thickness by a factor of $\sim 1.3$ and $\sim 1.5$, respectively, by replacing the $\mathrm{Al}$ back metallization with a bilayer of $\mathrm{ZnO} / \mathrm{Ag}$.

$F\left(t_{e p i, A l}\right)=\frac{t_{e p i, A l}}{t_{\text {epi,Zno/Ag }}}=\frac{1}{\frac{t_{0, Z n O / A g}}{t_{0, A l}}+\frac{t_{0, Z n O / A g}}{t_{e p i, A l}} \ln \left(\frac{x_{1, Z n O / A g}}{x_{1, A l}}\right)}$

To easily assess the suitability of our empirical expression relating the required bottom absorber thickness for current matching of top cell with given $\mathrm{Al}$ content, we have reported in Fig. 6(a) the tandem $\mathrm{J}_{\mathrm{sc}}$ calculated as a function of epi-SiGe thickness for both $\mathrm{Al}$ and $\mathrm{ZnO} / \mathrm{Ag}$ cases, considering matched sub cells currents. It can be noticed that $\mathrm{J}_{\mathrm{sc}}$ follows an asymptotic behavior and that $\mathrm{ZnO} / \mathrm{Ag}$ is indeed able to enhance $\mathrm{J}_{\mathrm{sc}}$, e.g. by $\sim 2.5 \mathrm{~mA} / \mathrm{cm}^{2}$ for $t_{\text {epi }}=5 \mu \mathrm{m}$ compared to the $\mathrm{Al}$ case. From Fig. 6(a), we can also remark that $F$ is $\sim 1.56$ for $t_{\text {ep } i}$
$=15 \mu \mathrm{m}$, confirming the previously predicted value of the thickness reduction factor. For $t_{\text {epi }}>15 \mu \mathrm{m}$, some oscillations are present for the $\mathrm{ZnO} / \mathrm{Ag}$ case, the same as in Fig. 5, therefore making it difficult to give the corresponding $F$ value. Note that the error bars do not correspond to the simulation precision (this one is estimated to the order of $10^{-2} \mathrm{~mA} . \mathrm{cm}^{-2}$ ) but represent the value by which the $J_{\mathrm{sc}}$ is underestimated, using the current matching empirical expressions previously determined. These error bars are calculated by subtracting the tandem $J_{\text {sc }}$ from the mean value of the top and the bottom $J_{\text {sc }}$. In other words, it is the remaining mismatch of current between top and bottom cells. As displayed in the figure, the error bars remain quite small: the mean relative error is $0.7 \pm 0.5 \%$ for $\mathrm{Al}$ case and is $0.9 \pm 0.7 \%$ for $\mathrm{ZnO} / \mathrm{Ag}$ case.

In addition, in Fig. 6(b) we report the $V_{\text {oc }}$ values of the tandem corresponding to the data in Fig. 6(a). The decreasing asymptotic behavior mostly reflects the evolution of the $\mathrm{Al}_{\mathrm{x}} \mathrm{Ga}_{1-\mathrm{x}} \mathrm{As}$ band gap with $t_{\text {epi }}$. Recombination losses due to radiative, Auger and SRH recombination in the top cell, the tunnel junction and the bottom cell result in an almost invariant value for the $\mathrm{W}_{\mathrm{oc}}[28]$ of the tandem, between $0.67 \mathrm{~V}$ and $\sim 0.7 \mathrm{~V}$, also represented in Fig. $6(\mathrm{~b})$. The tandem $\mathrm{W}_{\text {oc }}$ is defined as the sum of each sub cell $W_{o c}$ and is given by Eq. (6), where subscripts 1 and 2 for $\mathrm{W}_{\mathrm{oc}}, \mathrm{E}_{\mathrm{g}}$ and $\mathrm{V}_{\mathrm{oc}}$ refer to top and bottom cells $\mathrm{W}_{\mathrm{oc}}$, band gaps and open circuit voltages, respectively. The variations of $\mathrm{W}_{\mathrm{oc}, 1}$ and $\mathrm{W}_{\mathrm{oc}, 2}$ are also very small $(\sim 50 \mathrm{mV})$ and are not shown. a)

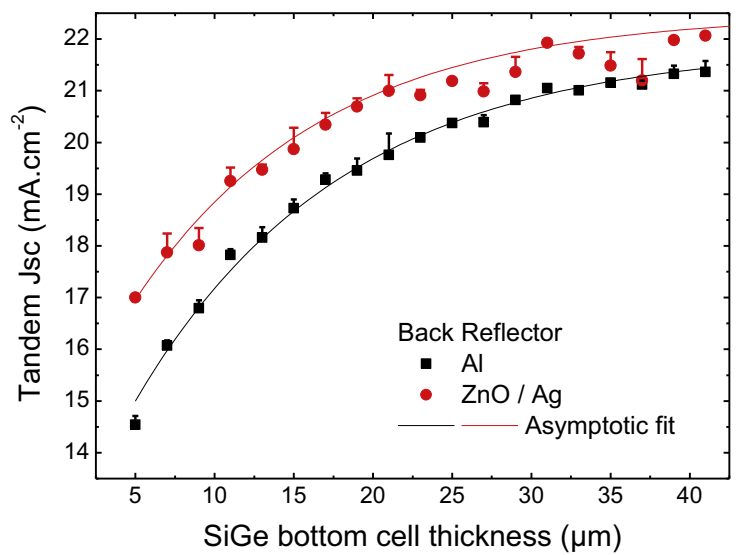

b)

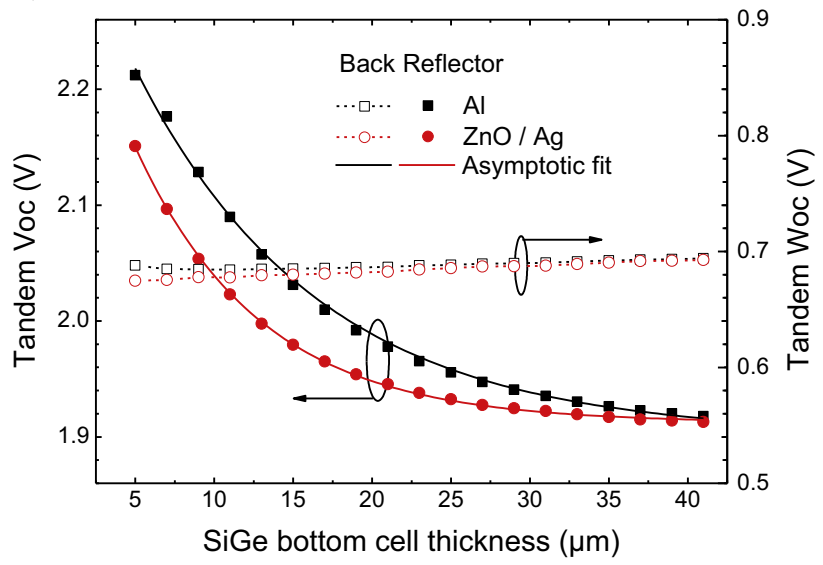

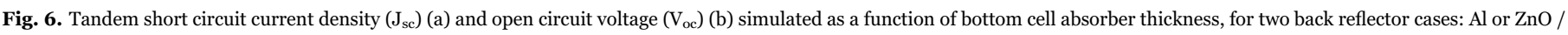

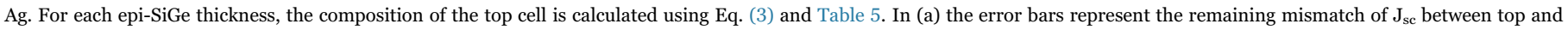
bottom cells. In (b) the $\mathrm{W}_{\text {oc }}[28]$ of the tandem cell is also represented on the right vertical axis. 
$W_{o c}=W_{o c, 1}+\quad W_{o c, 2}=\left(E_{g, 1}+E_{g, 2}\right) / q-V_{o c, 1}-V_{o c, 2}$

\subsubsection{RCWA optical model}

In the previous section, an optimization of the tandem device performance with flat back contact metallization schemes has been done as a function of the $\mathrm{Al}$ content in AlGaAs and the top cell base thickness. In order to achieve desired photogenerated current densities, the thickness of the SiGe bottom cell has been adjusted and in some cases reached tens of micrometers. While calculations on such flat devices provide an efficient platform to study tandem device efficiency, the minimal absorber thicknesses are desired to reduce fabrication cost. In this section, improved light trapping scheme based on nanostructuring is used to reduce the thickness of the bottom cell, while providing the same photogenerated current as its flat alternative. The absorption enhancement comes from the increased average light path by diffracting light in into different directions and achieving total reflectance condition on the flat top cell interface for the diffracted light.

To compare RCWA optical models with the previous opto-electrical calculations using TMM, we have fixed the top cell $\mathrm{Al}$ content at $17 \%$. This value corresponds, as shown in Fig. 5(a), to the best achievable efficiency of $36 \%$ when the current-matching conditions are respected. The used material parameters and thicknesses are the same than in Table 1. First, we have modeled the tandem cell with a flat $\mathrm{ZnO} / \mathrm{Ag}$ back reflector, and adjusted the thickness of the $\mathrm{Si}_{0.73} \mathrm{Ge}_{0.27}$ absorber to match a current of the front cell of $21.2 \mathrm{~mA} \mathrm{~cm}^{-2}$. Top cell photogenerated current density is obtained by summing up contributions of window, emitter and base layers. Note that the value is higher than in the previous opto-electric simulations due to neglecting all effects of imperfect carrier collection, thus assuming internal quantum efficiency equal to $100 \%$. Reaching this high value of the balanced photogenerated current density requires relatively large thickness of SiGe of about $17 \mu \mathrm{m}$ when thin $\mathrm{ZnO}$ layer on $\mathrm{Ag}$ substrate is used as the back reflector. The optimum SiGe thickness found with our optical model is in a good agreement with the previous calculations with the electrical model and values from Eq. (4). The absorptances and photogenerated current densities are shown in Fig. 7(a) for each active layer separately. Note that the front cell photogenerated current density is calculated as the sum of the values obtained in window, emitter, and base layers. Total absorptance in Fig. 7(a) shows that there are no reflection losses for wavelengths between 400 and $800 \mathrm{~nm}$, but there are losses in reflection for longer wavelengths. This is due to a limited capacity of

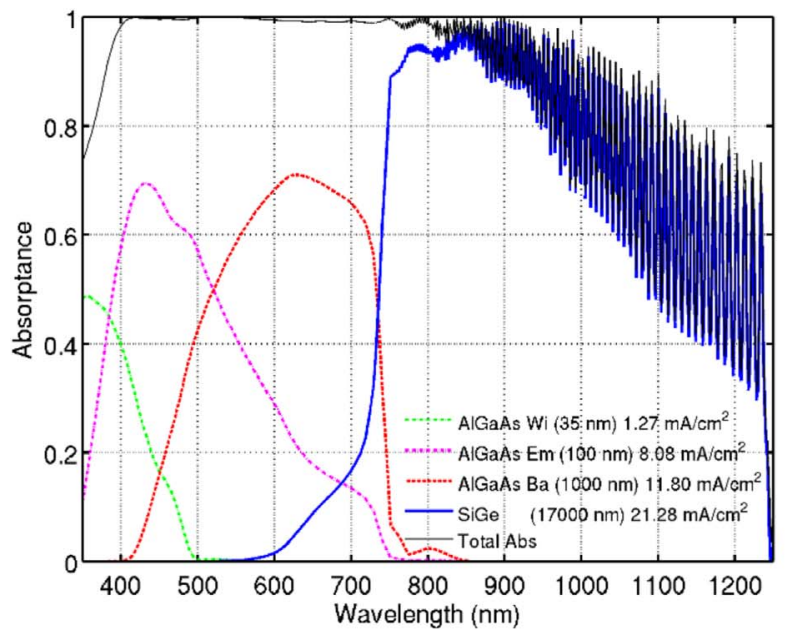

$\mathrm{SiO}_{2} / \mathrm{TiO}_{2}$ antireflective coating to improve the light absorption in materials with low absorption coefficient (SiGe in this case).

To improve the light trapping inside this tandem solar cell, we propose to improve the back side of the cell by nanostructurization in order to reduce reflection losses and more importantly increase the propagation angles inside the SiGe absorber. As already mentioned in the introduction, in our fabrication process, we use an inverse metamorphic approach. The AlGaAs front cell is fabricated at first using Metal Organic Chemical Vapor Deposition (MOCVD). and SiGe is grown afterwards on the top of it using low-temperature PECVD epitaxial growth process [3]. With this inverse metamorphic approach, we finish the growth by the SiGe material which will be the bottom cell. We have thus the possibility to nanostructurate the SiGe backside before transferring it to the host substrate. Therefore, we have simulated an effect of the 2D line grating at the backside of the cell, schematically depicted in Fig. 7(b), on the overall absorption performance.

The grating pitch was chosen to be $750 \mathrm{~nm}$ to have a sufficient number of diffraction orders propagating in SiGe material. After an optimization, a $200 \mathrm{~nm}$ thick $\mathrm{SiGe} / \mathrm{ZnO}$ grating with a fill factor of 0.62 (that is $62 \%$ of SiGe and $38 \%$ of $\mathrm{ZnO}$ material) on the top of the $150 \mathrm{~nm}$ thick $\mathrm{ZnO}$ film covering the $\mathrm{Ag}$ substrate has been proposed. Using this nanostructured backside, the $\mathrm{Si}_{0.73} \mathrm{Ge}_{0.27}$ film thickness required for matching the front cell current has been reduced to $8.5 \mu \mathrm{m}$ instead of $17 \mu \mathrm{m}$, leading to a similar photogenerated current of $21 \mathrm{~mA} \mathrm{~cm}{ }^{-2}$. The absorptance curves, film thicknesses and integrated photogenerated current densities for each active layer of the tandem cell are shown in Fig. 7(b). The effect of the light trapping is best seen in the near infrared spectral region, where the light absorption has been increased and there are some visible "peaks" coming from the propagating diffraction orders.

Detailed distribution of the square of the absolute value of the electric field intensity $|E|^{2}$ at the cross-section of the flat and nanostructured backreflector devices are shown for wavelengths of 500, 750 and $1000 \mathrm{~nm}$ in Fig. 8(a) and (b), respectively. The distribution at $500 \mathrm{~nm}$ is the same for the flat case as well as for the nanostructured one, as there is no light penetrating the top cell at this wavelength. At the wavelength of $750 \mathrm{~nm}$, where all active materials contribute to the photocurrent generation (see Fig. 7), the $|E|^{2}$ distribution is radically different between the flat and the nanostructured devices and it can be observed that the grating already contributes to an increased light absorption. Values of $|E|^{2}$ in SiGe are much higher closer to the backside of the bottom cell. The most radical

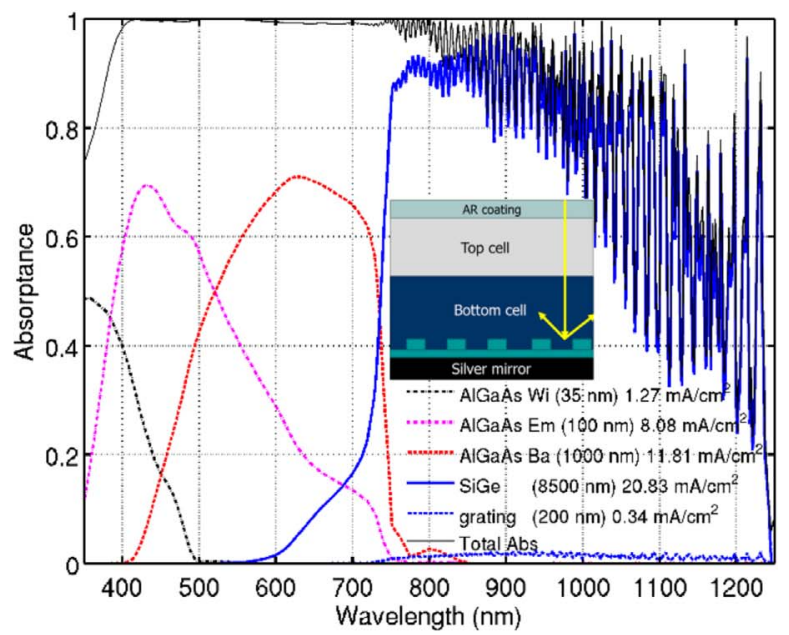

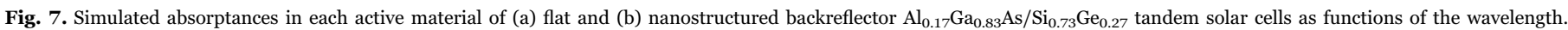

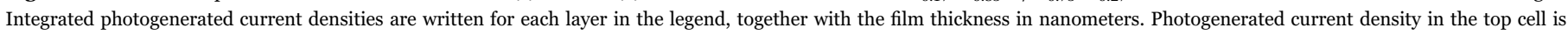

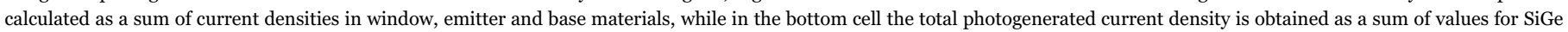
and grating layers. 

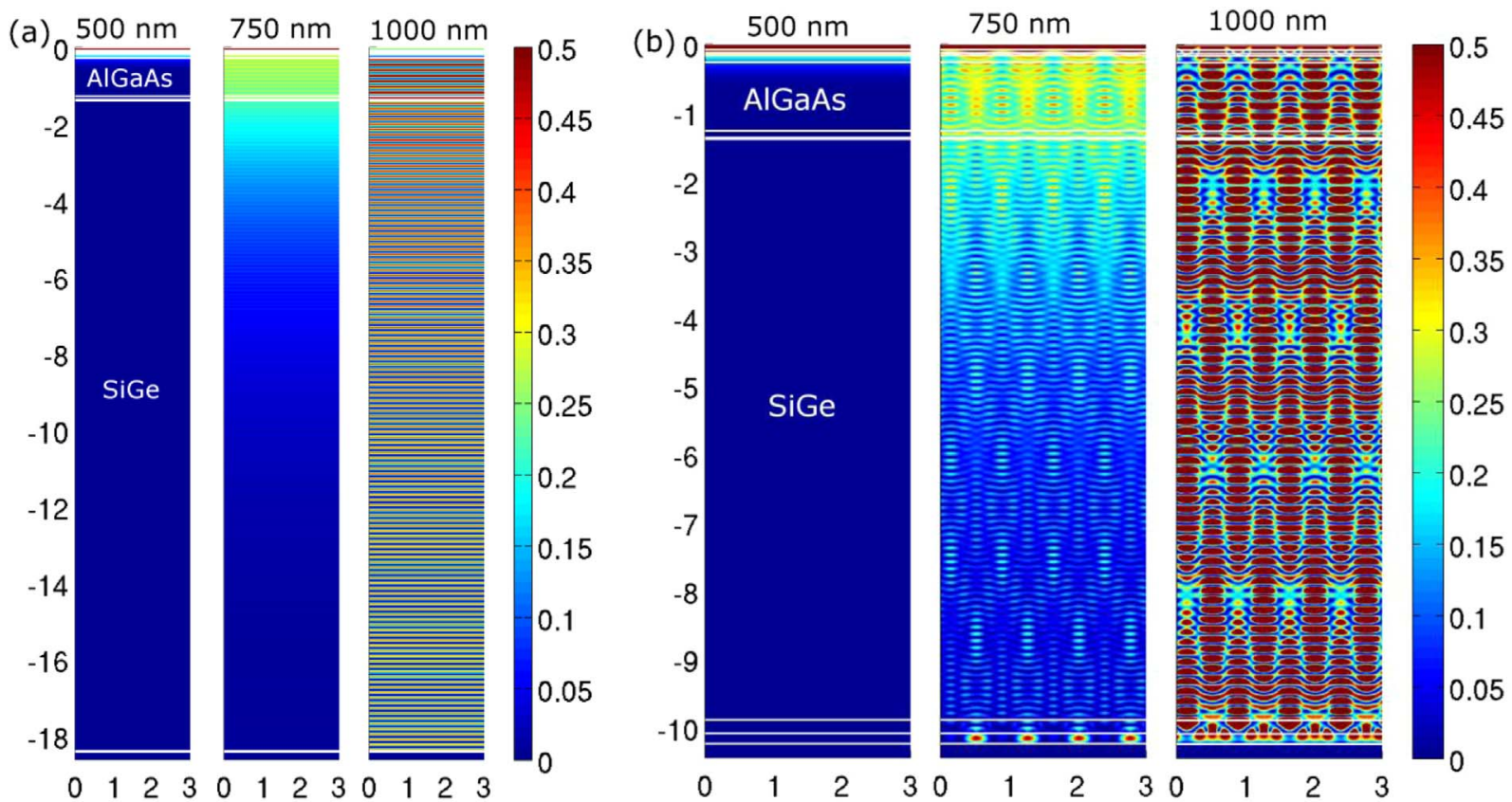

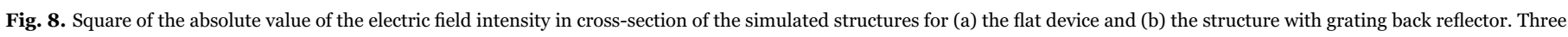

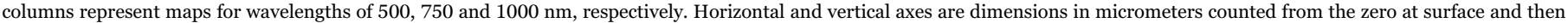
decreasing when inside the structure. Color scale of the electric field intensity is shown on the side. White horizontal lines mark interfaces between different materials.

change is at $1000 \mathrm{~nm}$ wavelength, selected from the spectral region, where the top cell is transparent. Values of $|E|^{2}$ for the structure with grating back reflector in Fig. 8(b) show very strong enhancement in the SiGe region with the field composed of multiple propagating diffraction orders. In comparison, the $|E|^{2}$ values at the cross-section of the flat device in Fig. 8(a) has at the wavelength of $1000 \mathrm{~nm}$ noticeably smaller values. This is due to the light trapping enhancement by the diffraction grating, which achieves a "compression" of the same amount of the electromagnetic field inside the smaller volume. As the local electromagnetic field absorption is proportional to $|E|^{2}$ and the complex part of the permittivity tensor (which is everywhere in SiGe constant for a given wavelength), this explains the higher light trapping efficiency of the device with nanostructured backreflector.

With a grating, the current-matching conditions for a fixed $17 \% \mathrm{Al}$ content have been found using an optical model for a $\mathrm{Si}_{0.73} \mathrm{Ge}_{0.27}$ thickness of $8.5 \mu \mathrm{m}$. For the flat device and using the same optical model, we have achieved the same current matching with $21 \mathrm{~mA} / \mathrm{cm}^{2}$ in each subcell for a SiGe thickness of $17 \mu \mathrm{m}$. Therefore, using a periodic grating allows to have the same cells performances but with a SiGe film thickness reduced by $50 \%$, which is very important in a thinfilm approach and has a tremendous impact on the cost of the device as short deposition time reduces the fabrication cost.

\subsection{Influence of the effective diffusion length in the epi-SiGe layer}

The objective of this section is to determine the influence of the effective diffusion length parameter $L_{\boldsymbol{d}}$ (defined by Eq. (1) in 2.3) on the tandem performance. At this stage it is important to recall that the same $L_{\boldsymbol{d}}$ value can be obtained either with bulk or interface defects and that $L_{d}$ also depends on the absorber thickness. Therefore, the interface and bulk defects densities $N_{i}$ and $N_{b}$ have been varied independently to show their individual influence on the tandem performance for an arbitrarily fixed bottom thickness. The studied cell, considered as the reference here, is composed of an $\mathrm{Al}_{0.15} \mathrm{Ga}_{0.85}$ As top cell and a $39 \mu \mathrm{m}$ thick epi-Si $\mathrm{Si}_{0.73} \mathrm{Ge}_{0.27}$ bottom cell, with a $\mathrm{ZnO} / \mathrm{Al}$ back reflector. Its reference AM1.5 g J(V) photovoltaic output parameters are: $\mathrm{J}_{\mathrm{sc}}$ $=21.2 \mathrm{~mA} \mathrm{~cm}^{-2}, \mathrm{~V}_{\mathrm{oc}}=1.93 \mathrm{~V}$ and $\mathrm{FF}=90 \%$ resulting in a conversion efficiency of $36.8 \%$. The ranges of variation of the defect densities are from $2 \times 10^{10} \mathrm{~cm}^{-2}$ to $8 \times 10^{12} \mathrm{~cm}^{-2}$ for $N_{i}$ and from $1 \times 10^{12} \mathrm{~cm}^{-3}$ to $3 \times 10^{15} \mathrm{~cm}^{-3}$ for $N_{b}$ (defects have negligible effects on the device performance for $N_{i}<2 \times 10^{10} \mathrm{~cm}^{-2}$ and $N_{b}<1 \times 10^{12} \mathrm{~cm}^{-3}$ ). For the sake of comparison, $\mathrm{J}_{\mathrm{sc}}, \mathrm{V}_{\mathrm{oc}}, \mathrm{FF}$ and efficiency have been normalized to their reference value and have been reported in Fig. 9 as a function of $L_{d}$.

At first we observe that the two $\mathrm{V}_{\text {oc }}$ curves are superimposed and follow the same logarithmic trend regardless the origin of the limitation of the $L_{d}$ value ( $N_{b}$ for open symbols and $N_{i}$ for full symbols). To explain this, remember that $\mathrm{V}_{\mathrm{oc}}$ is the voltage needed for the solar cell device to see all its photogenerated carriers recombined. As $L_{d}$ is linked to the total average recombination rate in the bottom cell at $V_{\text {oc }}$, it is not surprising to observe the same $\mathrm{V}_{\mathrm{oc}}$ for the same $L_{d}$.

Secondly, an important result is the invariance of $\mathrm{J}_{\mathrm{sc}}$ in the simulated range $40 \mu \mathrm{m}<\mathrm{L}_{\mathrm{d}}<500 \mu \mathrm{m}$ (full and open symbols). Indeed, the estimated value of $L_{\boldsymbol{d}}$ using experimentally extracted bulk

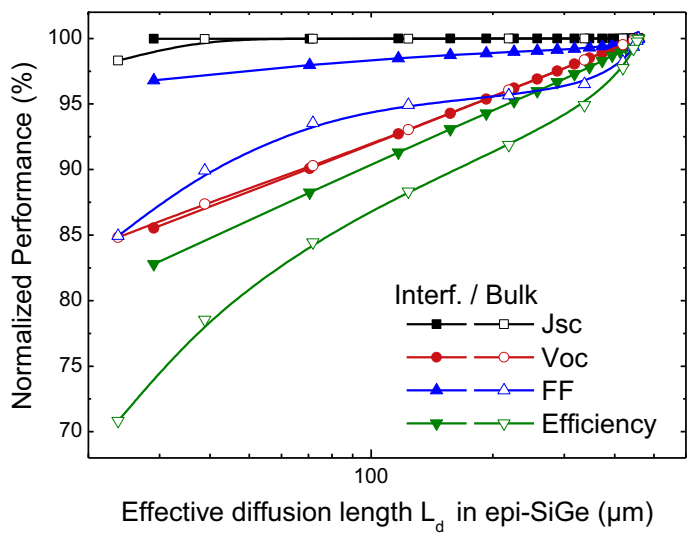

Fig. 9. Normalized $J_{s c}, V_{o c}, F F$ and Efficiency of the tandem cell as a function of the effective diffusion length $\left(L_{d}\right)$ in the bottom cell absorber showing the separate influence of the interface defects (full symbols) and bulk defects (open symbols). The reference cell (with no defects and the highest $L_{d}$ ) is composed of an $\mathrm{Al}_{0.15} \mathrm{Ga}_{0.85} \mathrm{As}$ top cell and a $39 \mu \mathrm{m}$ thick epi- $\mathrm{Si}_{0.73} \mathrm{Ge}_{0.27}$ bottom cell. The reference AM1.5 $\mathrm{g} \mathrm{J}(\mathrm{V})$ photovoltaic output parameters are: $\mathrm{J}_{\mathrm{sc}}=21.2 \mathrm{~mA} \mathrm{~cm}^{-2}, \mathrm{~V}_{\mathrm{oc}}=1.93 \mathrm{~V}$ and $\mathrm{FF}=90 \%$ resulting in a conversion efficiency of $36.8 \%$. 
Table 6

Bulk and interface defects densities fixed in scenarios 1, 2 and 3 .

\begin{tabular}{lll}
\hline Scenario & Bulk defects density $N_{b}\left(\mathrm{~cm}^{-3}\right)$ & Interface defects density $N_{i}\left(\mathrm{~cm}^{-2}\right)$ \\
\hline 1 & $10^{10}$ & $10^{8}$ \\
2 & $10^{10}$ & $2.9 \times 10^{12}$ \\
3 & $10^{14}$ & $2.9 \times 10^{12}$ \\
\hline
\end{tabular}

and interface defects densities in 2.3, is $\sim 95 \mu \mathrm{m}$ in the present $39 \mu \mathrm{m}$ thick epi-SiGe bottom cell down to $\sim 43 \mu \mathrm{m}$ in $5 \mu \mathrm{m}$ thick epi-SiGe. The latter results enable us to claim that (i) the electrical quality of the epiSiGe material ensures a very high carrier collection efficiency close to $100 \%$ and (ii) there is no need to take defects into account to determine current matching conditions: those previously calculated in 3.1 in the ideal case are still very suitable. In fact, bulk defects start to have an influence on $\mathrm{J}_{\mathrm{sc}}$ as the effective diffusion length in the defective bulk of the material becomes of the same order of magnitude than the epi-SiGe thickness $(39 \mu \mathrm{m})$, unsurprisingly.

Finally, the discrepancy between the effects of bulk and interface defects is seen on FF variations. For a given $L_{d}$, FF and efficiency are lower if $L_{d}$ is rather determined by the the bulk of epi-SiGe instead of by its interfaces.

\subsection{Different scenarios for the prediction of the tandem performance}

In this section we make use of insights gained in previous sections to give predictions of the tandem cell performance according to three different scenarios, for which the interface and bulk defects densities in the $\mathrm{Si}-\mathrm{Ge}$ layer are varied. Their respective values are detailed in Table 6.

Scenario \# 1 approaches an ideal case with no defects in the bottom cell. The interface and bulk defects densities are fixed to very low values so that SRH recombination is negligible with respect to intrinsic recombination (Auger and radiative). Scenario \#2 represents a case where the performance is limited by interface defects (no bulk defects). Their density is fixed to the value extracted in 2.3 for the $1.9 \mu \mathrm{m}$ thick epi-SiGe fabricated cell. In last scenario \#3, both bulk and interface defects are introduced. The bulk defects density is fixed to the value also extracted from the fabricated cell, keeping the interface defects density unchanged with respect to scenario $\# 2$.

Tandem efficiencies regarding scenarios \#1, \#2 and \#3 have been simulated as a function of epi-SiGe thickness $\left(t_{\text {epi }}\right)$ for the two simple back reflector cases: $\mathrm{Al}$ or $\mathrm{ZnO} / \mathrm{Ag}$. Results are shown in Fig. 10. We observe a decrease of the efficiency curves when going from scenario \#1 (squares), to scenario \#2 (rounds) and scenario \#3 (triangles) due to increased recombination in the bottom cell (only impacting $\mathrm{FF}$ and $\mathrm{V}_{\mathrm{oc}}$, c.f. 3.2).

By first focusing on the $\mathrm{Al}$ reflector case, we notice that about $26.3 \%$ efficiency is obtained for $t_{\text {epi }}=5 \mu \mathrm{m}$ in scenario \#2, resulting in around $3 \%$ absolute efficiency loss compared to the ideal scenario \#1. This difference, showing the impact of the presence of the interface defects only, remains almost the same for the entire range of $t_{\text {epi }}$. Interestingly, for $t_{\text {epi }}$ ranging from $5 \mu \mathrm{m}$ to $9 \mu \mathrm{m}$, the difference between efficiency curves $\# 2$ and $\# 3$ is very low ( $\sim 0.2 \%$ in absolute), correlated to a very small change of $L_{d}(43 \mu \mathrm{m}$ instead of $46 \mu \mathrm{m})$. This means that the bulk defects introduced in \#3 do not severely limit the performance in this range of bottom thickness. In turn, we can infer that the key parameter to be optimized experimentally in priority is the interfaces quality. Above $9 \mu \mathrm{m}$, the efficiency curve \#3 starts to diverge from curve \#2. In fact, in this thickness range, the tandem performance becomes more and more limited by the bulk quality as $t_{\text {epi }}$ increases. The tandem efficiency saturates to $\sim 31 \%$ at $25 \mu \mathrm{m}$ in scenario \#3 while it goes beyond $\sim 32 \%$ in $\# 2$ and $35.5 \%$ in \#1. Therefore, it is important to keep improving the bulk quality, especially if the targeted bottom thickness lies within this range.

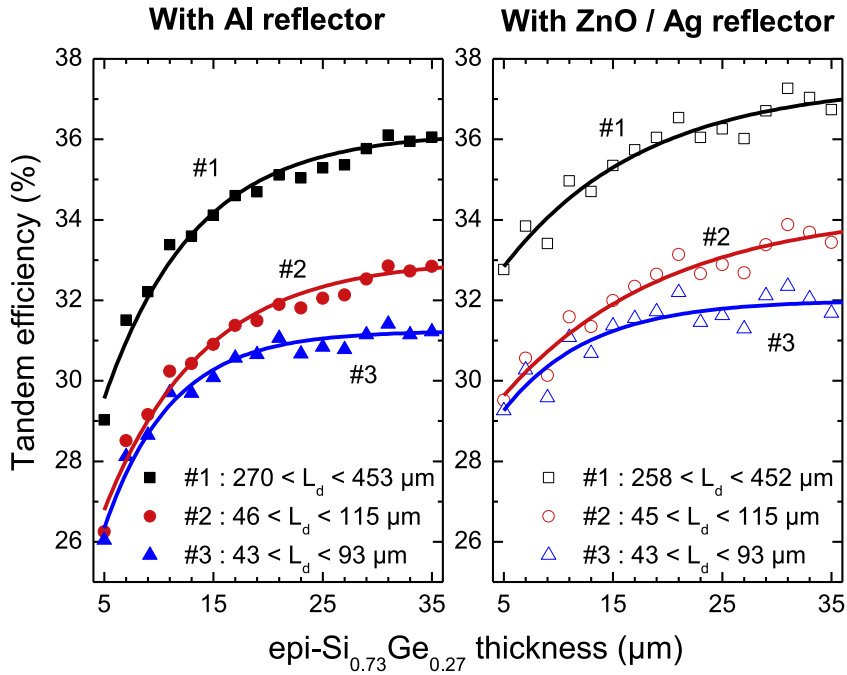

Fig. 10. Simulated tandem cell efficiency as a function of bottom cell absorber thickness for three different scenarios \#1, \#2 and \#3 and for two different back reflectors: Al reflector (left) and $\mathrm{ZnO} / \mathrm{Ag}$ reflector (right). The ranges of the calculated $L_{d}$ are also given in each scenario: the lowest (highest) value of $L_{d}$ corresponds to the smallest (biggest) epi-SiGe thickness. \#1: no defects. \#2: interface defects only. \#3 interface and bulk defects. Interface and bulk defects densities are given in Table 6 .

Finally, similar observations can be made in both back reflector cases. The $\mathrm{ZnO} / \mathrm{Ag}$ metallization still allows to reach higher efficiencies for thin epi-SiGe layers. Indeed, over 30\% efficiency can be obtained in both scenarios \#2 and \#3 with only $~ 7 \mu \mathrm{m}$ of epi-SiGe and $\mathrm{ZnO} / \mathrm{Ag}$ back metallization.

\section{Conclusions}

We have first presented the validation of both our AlGaAs top cell and our epi-Si(Ge) bottom cell models by performing the simulation of previously published fabricated solar cell performance data. Important material parameters were provided as well as fitting values for the model parameters when needed. A good agreement has been obtained between theoretical models and experimental data, testifying the suitability of our simulations to provide realistic predictions of III-V/ epi-SiGe tandem solar cells performance. This validation step also enabled us to assess the electrical quality inside the epitaxial silicon or silicon-germanium materials by retrieving the bulk and interface defects densities but also the effective diffusion length $L_{d}$ in fabricated single heterojunction solar cells made out of epi-Si(Ge) absorbers. $L_{d}$ values of $\sim 16 \mu \mathrm{m}$ and $\sim 9 \mu \mathrm{m}$ could be obtained for $4.2 \mu \mathrm{m}$ thick epi-Si and $1.9 \mu \mathrm{m}$ thick epi-SiGe, respectively. We have also investigated the impact of using light trapping schemes at the bottom of the tandem device to enhance the light absorption inside the thin films of epi-SiGe. Three different back metallization configurations were studied: a simple aluminum layer, a bilayer of $\mathrm{ZnO}$ on silver and a $2 \mathrm{D}$ grid composed of $\mathrm{SiGe} / \mathrm{ZnO}$ grating on $\mathrm{ZnO}$ and silver substrate. We have thus shown that using a 2D grating, the bottom epi-SiGe thickness can be reduced by a factor of 2 for the same performance as for the thick flat device. However we have also shown that the optimal $\mathrm{Al}$ content in the AlGaAs top cell should be readjusted for each of these three metallization cases to achieve current matching for a given bottom cell absorber thickness. We have provided a simple empirical expression relating the required bottom absorber thickness to the $\mathrm{Al}$ content for the matching of the currents of the flat tandem device. Finally, we have presented an in-depth analysis of both bottom cell interface and bulk defects influence on the tandem cell performance. Three different scenarios for the prediction of the tandem performance have been discussed with different interface and bulk defect densities. Our results show that the electrical quality of the epi-SiGe material ensures a very high carrier collection efficiency. $L_{d}$ values of $\sim 43 \mu \mathrm{m}$ and $\sim 95 \mu \mathrm{m}$ 
could be obtained for $5 \mu \mathrm{m}$ thick and $39 \mu \mathrm{m}$ thick bottom cells, using the previously determined bulk and interface defects density values for epi-SiGe, further proving the relevance of using low temperature PECVD epitaxy for the fabrication of high quality bottom cells. Performance is mainly affected by interface defects for epi-SiGe thicknesses below $9 \mu \mathrm{m}$ and by bulk defects above this value. Therefore, interfaces quality is a key parameter to improve during the device fabrication, especially if light trapping schemes are used to reduce the required bottom absorber thickness. Finally, we have shown that over $30 \%$ efficiency could be achieved for the tandem with only $7 \mu \mathrm{m}$ of epi-SiGe and $\mathrm{ZnO} / \mathrm{Ag}$ back metallization in the most pessimistic scenario, which represents an absolute efficiency difference of $\sim 3.5 \%$ compared to the ideal case. In the latter ideal scenario, the highest efficiency achievable is $~ 37 \%$ with $1.1 \mu \mathrm{m}$ thick $\mathrm{Al}_{0.15} \mathrm{Ga}_{0.85} \mathrm{As}$ top cell and epi-Si $\mathrm{Si}_{0.73} \mathrm{Ge}_{0.27}$ bottom cell less than $~ 30 \mu \mathrm{m}$ thick.

\section{Acknowledgements}

This work has been carried out within the IMPETUS project $\mathrm{N}^{\circ}$ ANR-13-PRGE-0009-03. The author would like to acknowledge CNRS and the French National Research Agency for funding and Dr Sylvain Le Gall for fruitful discussions during the preparation of the paper.

\section{References}

[1] J.P. Connolly, D. Mencaraglia, C. Renard, D. Bouchier, Designing III-V multijunction solar cells on silicon, Prog. Photovolt. Res. Appl (2014). http://dx.doi.org/ 10.1002/pip.2463.

[2] M.A. Green, Silicon wafer-based tandem cells: The ultimate photovoltaic solution?, in: 2014: p. 89810L-89810L-6. doi:10.1117/12.2044175

[3] R. Cariou, W. Chen, J.-L. Maurice, J. Yu, G. Patriarche, O. Mauguin, L. Largeau, J. Decobert, P. Roca i Cabarrocas, Low temperature plasma enhanced CVD epitaxial growth of silicon on GaAs: a new paradigm for III-V/Si integration, Sci. Rep. 6 (2016) 25674. http://dx.doi.org/10.1038/srep25674.

[4] M.A. Green, Silicon wafer-based tandem cells: The ultimate photovoltaic solution?, in: 2014: p. 89810L-89810L-6. doi:10.1117/12.2044175

[5] T.P. White, N.N. Lal, K.R. Catchpole, Tandem solar cells based on high-efficiency cSi bottom cells: top cell requirements for $>30 \%$ efficiency, IEEE J. Photovolt. 4 (2014) 208-214. http://dx.doi.org/10.1109/JPHOTOV.2013.2283342.

[6] M. Yamaguchi, K.-H. Lee, K. Araki, N. Kojima, Y. Ohshita, Potential and Activities of III-V/Si Tandem Solar Cells, Ecs J. Solid State Sci. Technol. 5 (2016) Q68-Q73. http://dx.doi.org/10.1149/2.0311602jss.

[7] I. Mathews, D. O’Mahony, B. Corbett, A.P. Morrison, Theoretical performance of multi-junction solar cells combining III-V and Si materials, Opt. Express 20 (2012) A754-A764.

[8] K.J. Schmieder, III-V/SiGe tandem solar cells on Si substrates, University of Delaware, 2013. http://gradworks.umi.com/35/94/3594969.html (accessed June 23, 2014).

[9] M. Diaz, L. Wang, D. Li, X. Zhao, B. Conrad, A. Soeriyadi, A. Gerger, A. Lochtefeld, C. Ebert, R. Opila, I. Perez-Wurfl, A. Barnett, Tandem GaAsP/SiGe on Si solar cells, Sol. Energy Mater. Sol. Cells 143 (2015) 113-119. http://dx.doi.org/10.1016/ j.solmat.2015.06.033.
[10] V. Vijayakumar, D.P. Birnie III, Optical and electronic simulation of gallium arsenide/silicon tandem four terminal solar cells, Sol. Energy 97 (2013) 85-92. http://dx.doi.org/10.1016/j.solener.2013.07.033.

[11] M. Umeno, T. Kato, T. Egawa, T. Soga, T. Jimbo, High efficiency AlGaAs/Si tandem solar cell over 20\%, Sol. Energy Mater. Sol. Cells $41-42$ (1996) 395-403. http:// dx.doi.org/10.1016/0927-0248(95)00123-9.

[12] A. Rolland, L. Pedesseau, J. Even, S. Almosni, C. Robert, C. Cornet, J.M. Jancu, J. Benhlal, O. Durand, A.L. Corre, P. Rale, L. Lombez, J.-F. Guillemoles, E. Tea, S. Laribi, Design of a lattice-matched III-V-N/Si photovoltaic tandem cell monolithically integrated on silicon substrate, Opt. Quantum Electron. 46 (2014) 1397-1403. http://dx.doi.org/10.1007/s11082-014-9909-z.

[13] R. Cariou, J.-L. Maurice, J. Decobert, P. Roca i Cabarrocas, Direct epitaxial growth of silicon on GaAs by low temperature epitaxy, Photovolt. Spec. Conf. PVSC 2014 IEEE 40th. (2014) 2789-2791.

[14] R. Cariou, J. Tang, N. Ramay, R. Ruggeri, P. Roca i Cabarrocas, Low temperature epitaxial growth of SiGe absorber for thin film heterojunction solar cells, Sol. Energy Mater. Sol. Cells 134 (2015) 15-21. http://dx.doi.org/10.1016/j.solmat.2014.11.018.

[15] R. Lachaume, R. Cariou, J. Decobert, M. Foldyna, G. Hamon, P.R. i Cabarrocas, J. Alvarez, J.-P. Kleider, Performance analysis of AlxGa1-xAs/epi-Si(Ge) tandem solar cells: a simulation study, Energy Procedia 84 (2015) 41-46. http:// dx.doi.org/10.1016/j.egypro.2015.12.293.

[16] Silvaco User Manual, (2016). https://dynamic.silvaco.com/dynamicweb/jsp/ downloads/DownloadManualsAction.do?req=silen-manuals \& nm=atlas (accessed August 27, 2016)

[17] NSM Archive - Physical Properties of Semiconductors, (n.d.). http://www.ioffe.ru/ SVA/NSM/Semicond/ (accessed August 26, 2016)

[18] G. Létay, M. Hermle, A.W. Bett, Simulating single-junction GaAs solar cells including photon recycling, Prog. Photovolt. Res. Appl 14 (2006) 683-696. http:// dx.doi.org/10.1002/pip.699.

[19] G.B. Lush, B-coefficient in n-type GaAs, Sol. Energy Mater. Sol. Cells 93 (2009) 1225-1229. http://dx.doi.org/10.1016/j.solmat.2009.01.020.

[20] R. Cariou, M. Labrune, P. Roca i Cabarrocas, Thin crystalline silicon solar cells based on epitaxial films grown at $165{ }^{\circ} \mathrm{C}$ by RF-PECVD, Sol. Energy Mater. Sol Cells 95 (2011) 2260-2263. http://dx.doi.org/10.1016/j.solmat.2011.03.038.

[21] S. Cristoloveanu, I. Ionica, A. Diab, F. Liu, The Pseudo-MOSFET: principles and recent trends (Invited)ECS Trans. 50 (2013) 249-258. http://dx.doi.org/10.1149/ 05005.0249ecst.

[22] S. Chakraborty, R. Cariou, M. Labrune, P. Roca i Cabarrocas, P. Chatterjee, Feasibility of using thin crystalline silicon films epitaxially grown at $165{ }^{\circ} \mathrm{C}$ in solar cells: a computer simulation study, EPJ Photo. 4 (2013) 45103. http://dx.doi.org/ 10.1051/epjpv/2013014.

[23] M.G. Moharam, T.K. Gaylord, Diffraction analysis of dielectric surface-relief gratings, JOSA 72 (1982) 1385-1392. http://dx.doi.org/10.1364/ JOSA.72.001385

[24] L. Li, Formulation and comparison of two recursive matrix algorithms for modeling layered diffraction gratings, JOSA A 13 (1996) 1024-1035. http://dx.doi.org/ 10.1364/JOSAA.13.001024.

[25] L. Li, Use of Fourier series in the analysis of discontinuous periodic structures, JOSA A 13 (1996) 1870-1876. http://dx.doi.org/10.1364/JOSAA.13.001870.

[26] A. van Geelen, P.R. Hageman, G.J. Bauhuis, P.C. van Rijsingen, P. Schmidt, L.J. Giling, Epitaxial lift-off GaAs solar cell from a reusable GaAs substrate, Mater. Sci. Eng. B. 45 (1997) 162-171. http://dx.doi.org/10.1016/S0921-5107(96) 02029-6.

[27] S. Heckelmann, D. Lackner, C. Karcher, F. Dimroth, A.W. Bett, Investigations on AlxGa1-xAs solar cells grown by MOVPE, IEEE J. Photo. 5 (2015) 446-453. http:// dx.doi.org/10.1109/JPHOTOV.2014.2367869.

[28] R.R. King, D. Bhusari, A. Boca, D. Larrabee, X.-Q. Liu, W. Hong, C.M. Fetzer, D.C. Law, N.H. Karam, Band gap-voltage offset and energy production in nextgeneration multijunction solar cells, Prog. Photovolt. Res. Appl 19 (2011) 797-812. http://dx.doi.org/10.1002/pip.1044. 